\title{
Pterygium Surgery Utilizing Limbal Conjunctival Autograft and Subconjunctival Amniotic Membrane Graft in High-Risk Populations
}

This article was published in the following Dove Press journal: Clinical Ophthalmology

\author{
Alexander Shusko (D) \\ Barry A Schechter ${ }^{2}$ \\ John A Hovanesian (1D ${ }^{3}$ \\ 'Nassau University Medical Center, \\ Department of Ophthalmology, East \\ Meadow, NY II554, USA; ${ }^{2}$ Florida Eye \\ Microsurgical Institute, Boynton Beach, \\ FL 33426, USA; ${ }^{3}$ Harvard Eye Associates, \\ Laguna Hills, CA 92653, USA
}

\begin{abstract}
Objective: To measure the outcomes of primary pterygium excision with a limbal conjunctival autograft when combined with the adjunctive use of a prophylactic subconjunctival graft of amniotic membrane to decrease the recurrence rate after surgery in an ethnically diverse population with a statistically higher risk for recurrence (African American, Asian, Caribbean, Asian, Latin).
\end{abstract}

Design: This is a retrospective, non-comparative study of post-operative outcomes.

Participants: A total of 355 patients, totaling 493 eyes, with clinically significant, primary pterygia.

Patients and Methods: Patients were enrolled into the study based on the need for pterygium surgery and if they underwent primary pterygium excision with conjunctival autograft with subconjunctival amniotic membrane placement. Patients with recurrent pterygium or those with pseudopterygium were excluded from this study. All surgeries took place at the Florida Eye Microsurgical Institute (Boynton Beach, FL) between June 2006 and October 2013 by a single surgeon (BAS). Patients were seen on post-operative day 1, 7, 30, 90,180 and 365 to evaluate for pterygium recurrence. Pterygium recurrence is defined in this study as growth greater than $1 \mathrm{~mm}$ past the corneal limbus at or after 6 months.

Results: There were six cases of recurrent pterygium for a recurrence rate of $1.22 \% \pm 0.97 \%$ $(\mathrm{n}=493, \mathrm{p}=0.05)$. Follow-up ranged from 6 months to 6 years (mean 28 months).

Conclusion: Primary pterygium excision with a limbal conjunctival autograft and placement of a subconjunctival amniotic membrane graft has a low recurrence rate consistent with previously published data.

Keywords: pterygium, autograft, amniotic graft, technique, recurrence, cornea

\section{Introduction}

Pterygia excision techniques have improved over the years; from the bare sclera technique that was first documented by Celsus in A.D. 25 to the PERFECT technique used and taught by Dr Hirst in Australia., ${ }^{1,2}$ Today's most common technique, pterygium excision with a conjunctival autograft, has a recurrence rate of $5 \%{ }^{3}$ Published results of surgical outcomes using a pterygium excision technique involving a combination of a limbal conjunctival autograft and a prophylactic subconjunctival amniotic membrane graft showed a recurrence rate of $1 \% .{ }^{4}$ Patient ethnicity and geographic origin, major risk factors for pterygium recurrence, were not recorded in that study, which definitely impacts outcome and needed to be addressed.
Correspondence: Alexander Shusko Nassau University Medical Center, 220 Hempstead Turnpike, East Meadow, NY II554, USA

$\mathrm{Tel}+1$ 949-246-1737

Email ashusko@gmail.com 
The aim of this study was to evaluate the technique of pterygium excision with sutureless limbal conjunctival autograft with the addition of prophylactic placement of subconjunctival amniotic membrane. This study included a large sample size with varying ethnicity of patients undergoing the procedures. We hypothesize that the conjunctival autograft with subconjunctival amniotic membrane technique will continue to demonstrate low recurrence rates even in a population with high recurrence risk. $^{5-7}$

\section{Patients and Methods}

This retrospective case series study in which patient records with a diagnosis of primary pterygium that underwent surgical intervention in otherwise healthy eyes were examined. This is a retrospective study approved by the Florida Eye Microsurgical Institute and follows the tenets of the Declaration of Helsinki. Surgery was performed at the Florida Eye Microsurgical Institute (Boynton Beach, FL) between June 2006 and October 2013 by a single surgeon (BAS). This study is a separate from work published previously by Dr Hovanesian and Dr Shusko, though they collaborated in this study design, analysis, and writing. Patients' records must have had one follow-up examination at least six months after surgery and with the longest followup timeframe being 6 years. Patients were excluded if the primary diagnosis was recurrent pterygium or pseudopterygium. There were 3 patients who underwent surgery but were not included due to traumatic graft dehiscence in the first 2 weeks post-operative, which subsequently required surgical revision.

The initial size of the pterygium was measured preoperatively at a slit lamp, and notated in the medical record and used for later analysis.

Anesthesia was achieved using subconjunctival $0.025 \%$ bupivacaine to balloon up the area of the pterygium and underlying Tenon's fascia. Wescott scissors and toothed forceps were used to excise the pterygium while attempting to preserve the surrounding normal conjunctiva. The pterygium was dissected fully from the scleral to the corneoscleral limbus using toothed forceps and blunt Wescott scissors. Gentle traction with a cotton tip applicator was used while the pterygium was avulsed with toothed forceps. Fibrovascular Tenon's tissue was sharply dissected from the conjunctiva back towards the extraocular muscles. Wetfield cautery was utilized as necessary for hemostasis. Remaining adherent fibrovascular tissue was stripped using a rotating diamond burr to leave a smooth scleral bed. A subconjunctival pocket around the periphery of the excision site was created using blunt dissection of Wescott scissors to leave space for amniotic membrane placement later in the case.

Measurements of the scleral bed were taken using calipers. The measurements taken were used to determine the size of the conjunctival autograft. The measurements were then oversized by $1 \mathrm{~mm}$ in both the vertical and horizontal directions to ensure total coverage of the scleral bed excision site. The autograft was harvested from the superior conjunctiva with every effort to maintain a thin graft by minimizing the inclusion of Tenon's fascia. Using a diamond blade, the corneal epithelium was superficially scored $1 \mathrm{~mm}$ anterior to the limbal vasculature to theoretically include limbal stem cells. The conjunctival graft was left attached to the superior limbus while the amniotic membrane was being prepared.

A strip of dehydrated amniotic membrane tissue was cut to fit into the subconjunctival pocket created earlier. A small volume of fibrin sealant (Evicel, Johnson \& Johnson, OMRIX Biopharmaceuticals, Tel Aviv, Israel) was used to rehydrate the amniotic membrane. The membrane was then introduced into subconjunctival pocket. The amniotic membrane remained in the subconjunctival space and was covered by the bulbar conjunctiva surrounding the excision site.

The conjunctival graft was dissected from the superior limbus and moved onto the cornea. Taking care to maintain correct orientation, so that the limbal edge of the graft will align with the limbal edge of the pterygium site, the graft was rotated on the cornea to lay next the excision site. Thrombin was placed on the excision site and Fibrinogen is placed on the Tenon's fascia of the conjunctival graft.

Non-toothed forceps were used to evert the graft onto the scleral bed of the excision site. This allowed the thrombin and fibrinogen to begin mixing. The graft was gently smoothed and stretched to completely cover the sclera of the excision site. A cotton tip applicator was used to remove excess sealant. Excess graft tissue trimmed where necessary using Wescott scissors. To help keep the graft flat at the limbal edge, a bandage contact lens was placed. The bandage contact lens also assisted in reducing patient discomfort by covering the epithelial abrasion created by avulsing the pterygium.

Post-operatively, eyes were gently taped shut for an hour to minimize the chance of dislodging the grafts while the glue set. For the first week, topical medication included moxifloxacin $0.5 \%$ drops (Vigamox, Alcon, Ft. Worth, Texas) and bromfenac 0.09\% drops (Prolensa, Bausch \& Lomb, Rochester, NY). The bandage contact lens was removed at 


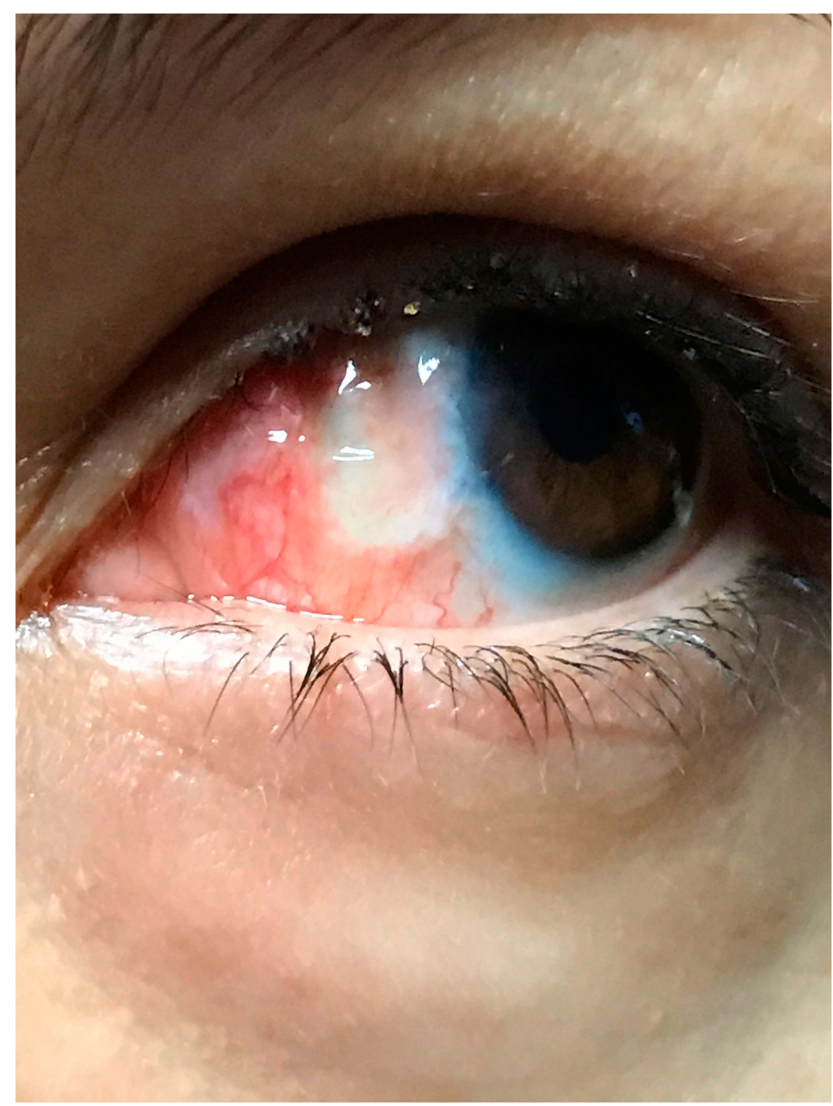

Figure I Example of a patient at post-operative day I results, notice the contact bandage lens and healing conjunctival graft.

post-operative week 1, once the corneal epithelium was completely healed. In addition, topical loteprednol drops (Lotemax, Bausch and Lomb, Rochester, NY) were used 4 times daily for the first 2 weeks followed by a weekly taper thereafter. Patients remained on the loteprednol once a day until the conjunctival graft was quiet. Patients were seen for a post-operative visit at 1 day (Figure 1) and then within a week after surgery (when the bandage lens was removed) and then at 1 month (Figure 2). Eyes were examined again at least 6 months post-operatively for signs of recurrence or complications and then annually for several years when patients kept their follow-up. All results were recorded.

Pterygium recurrence was the primary outcome measured. Pterygium recurrence is defined in this study as a regrowth of pterygium extending at least $1 \mathrm{~mm}$ onto the cornea past the limbus at any point in time during the patient's post-operative care.

\section{Results}

A total of 493 eyes of 355 patients underwent pterygium excision with a limbal conjunctival autograft and prophylactic placement of subconjunctival amniotic membrane. Pre-

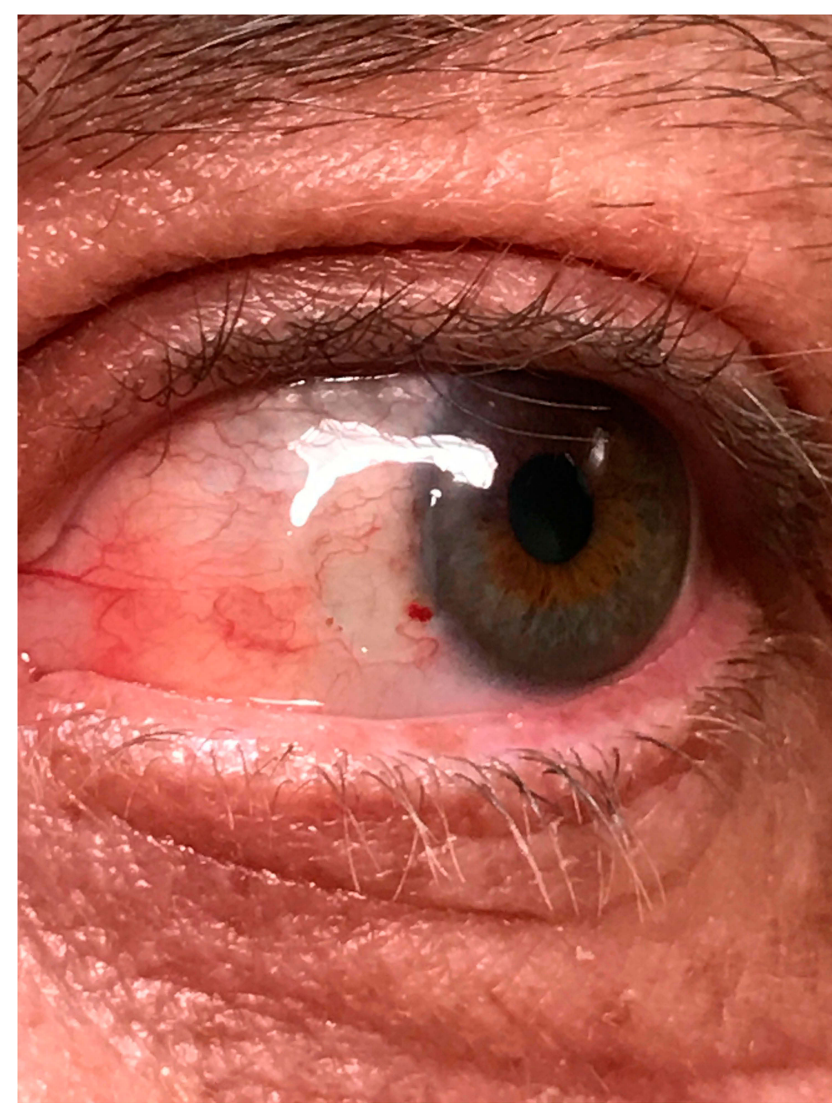

Figure 2 Example of a patient at post-operative day 30 results.

operatively, the average extent of horizontal growth of pterygia on the cornea was $2.47 \mathrm{~mm} \pm 0.82 \mathrm{~mm}$. The ethnicities of patients included were 58\% Caribbean/African American, 27\% Hispanic, 9.7\% Caucasian, and 5.3\% Asian. Follow-up ranged from 6 months to 6 years (mean 28 months).

There were six cases of recurrence in this data set for a recurrence rate of $1.22 \% \pm 0.99 \%(n=493, p=0.05)$.

\section{Discussion}

Pterygium excision with a conjunctival autograft has been considered the gold standard of primary pterygium treatment by corneal specialists. ${ }^{8}$ With this technique, recurrences still occur at a relatively high rate, especially in those at high risk. Recurrence rates from a recent Cochrane Eye and Vision Group meta-analysis of conjunctival autograft outcomes range from $3.33 \%$ to $16.7 \%{ }^{9}$

A conjunctival autograft and an amniotic membrane have their own strengths in preventing recurrence. The best replacement for conjunctiva is native conjunctiva, which is reflected in the recurrence rate with conjunctival grafting alone when compared to other single therapies. It is thought that conjunctival autografts create a barrier for the growth of 
any residual or recurrent fibrotic tissue. ${ }^{10}$ The subconjunctival fibroblasts associated with Tenon's fascia are considered to be the cells associated with pterygium recurrence. The stroma of the amniotic membrane is believed to suppress TGF- $\beta$ signaling and myofibroblast differentiation thus reducing scarring. ${ }^{10}$ Placing the amniotic membrane in the subconjunctival space creates direct contact with the fibroblasts associated with Tenon's fascia in turn decreasing pterygium recurrence. This data set further supports that the combination of conjunctival autograft and subconjunctival amniotic membrane placement lowers the pterygium recurrence rate below what can be achieved with either technique alone.

There were six cases of pterygium recurrence in this patient group. Despite meticulous surgery to remove as much Tenon's fascia, inflammatory conjunctiva, and subconjunctival tissue as possible, this small group of patients had recurrences. This technique appears to decrease the recurrence rate compared to the current standard of care, but there still remains an unknown reason for pterygium recurrence.

Points to consider when planning a pterygium excision with prophylactic subconjunctival amniotic membrane are the need for a moderate increase in surgical skill needed to place the amniotic membrane and increased surgical costs.

We believe to achieve a lower pterygium recurrence rate, the combination of limbal conjunctival autografts with a prophylactic subconjunctival amniotic membrane should be considered in when planning for a primary pterygium excision procedure. In this data set, using a limbal conjunctival autograft with placement of subconjunctival amniotic membrane, the recurrence rate was $1.22 \%$. When compared with the range of recurrence rates from the Cochrane meta-analysis, our results with the $95 \%$ confidence interval are below those included in the meta-analysis. This recurrence rate is also similar to a previously published outcome utilizing the same technique. ${ }^{4}$ Our patient population was larger and more diverse than the previous study and included ethnicities at high risk for pterygium recurrence. Additional studies will further define the patient populations that will likely to benefit from this procedure, we believe that the combination of techniques merits consideration, especially for high recurrence rate risk patients undergoing surgical removal of pterygium.

\section{Disclosure}

John A Hovanesian reports personal fees from Katena, during the conduct of the study. The authors report no funding and no other possible conflicts of interest in this work.

\section{References}

1. Sheppard J, Mansur A, Comstock TL, Hovanesian JA. An update on the surgical management of pterygium and the role of loteprednol etabonate ointment. Clin Ophthalmol. 2014:1105. doi:10.2147/opth. s55259

2. Hirst LW. Recurrent pterygium surgery using pterygium extended removal followed by extended conjunctival transplant: recurrence rate and cosmesis. Ophthalmology. 2009;116(7):1278-1286. doi:10.1016/j.ophtha.2009.01.044

3. Kenyon KR, Wagoner MD, Hettinger ME. Conjunctival autograft transplantation for advanced and recurrent pterygium. Ophthalmology. 1985;92(11):1461-1470. doi:10.1016/S0161-6420(85)33831-9

4. Shusko A, Hovanesian JA. Pterygium excision with conjunctival autograft and subconjunctival amniotic membrane as antirecurrence agents. Can J Ophthalmol. 2016;51(6):412-416. doi:10.1016/j.jcjo.2016.02.022

5. Luthra R. Frequency and risk factors for pterygium in the Barbados Eye Study. Arch Ophthalmol. 2001;119(12):1827. doi:10.1001/ archopht.119.12.1827

6. Nemesure B, Wu S-Y, Hennis A, et al. Nine-year incidence and risk factors for pterygium in the Barbados Eye Studies. Ophthalmology. 2008;115(12):2153-2158. doi:10.1016/j.ophtha.2008.08.003

7. Kandavel R, Kang JJ, Memarzadeh F, et al. Comparison of pterygium recurrence rates in hispanic and white patients after primary excision and conjunctival autograft. Cornea. 2010;29(2):141-145. doi:10.1097/ ico.0b013e3181b11630

8. Aminlari A, Singh R, Liang D. Management of pterygium. Ophthalmic Pearls. Cornea. 2014;37-38.

9. Clearfield E, Muthappan V, Wang X, Kuo IC. Conjunctival autograft for pterygium. Cochrane Database Syst Rev. 2016. doi:10.1002/ 14651858.CD011349.pub2

10. Fernandes M, Sangwan VS, Bansal AK, et al. Outcome of pterygium surgery: analysis over 14 years. Eye. 2005;19(11):1182-1190. doi:10.1038/sj.eye.6701728
Clinical Ophthalmology

\section{Publish your work in this journal}

Clinical Ophthalmology is an international, peer-reviewed journal covering all subspecialties within ophthalmology. Key topics include: Optometry; Visual science; Pharmacology and drug therapy in eye diseases; Basic Sciences; Primary and Secondary eye care; Patient Safety and Quality of Care Improvements. This journal is indexed on PubMed
Central and CAS, and is the official journal of The Society of Clinical Ophthalmology (SCO). The manuscript management system is completely online and includes a very quick and fair peer-review system, which is all easy to use. Visit http://www.dovepress.com/ testimonials.php to read real quotes from published authors.

\section{Dovepress}

